\title{
Identification and analysis of tumour-associated antigens in hepatocellular carcinoma
}

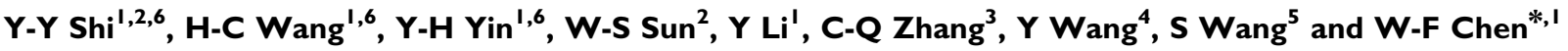 \\ 'Immunology Department, Peking University Health Science Center, Beijing 100083, China; ${ }^{2}$ Immunology Department, School of Medicine, Shandong \\ University, Jinan, China; ${ }^{3}$ Sun Yat-Sen University Cancer Center, Guangzhou, China; ${ }^{4}$ Cancer Biological Therapy and Diagnosis Center, Beijing Cancer \\ Hospital, Beijing, China; ${ }^{5}$ Department II of Surgery and Laboratory of Surgical Oncology, Peking University People's Hospital, Beijing, China
}

\begin{abstract}
To identify tumour and tumour-associated antigens in patients with hepatocellular carcinoma (HCC) one may find potential diagnostic markers and immunotherapeutic targets. In the current study, 30 distinct antigens reactive with serum IgG from HCC patients were identified by serological analysis of cDNA expression libraries (SEREX). The mRNA expression patterns of I 4 of these 30 antigens were altered in cancer as further revealed by cDNA microarray, with upregulation for nine and downregulation for five antigens. One of the upregulated antigens was cancer-testis (CT) antigen (CAGE), which had been previously reported to be expressed exclusively in normal gametogenic tissues and aberrantly expressed in a variety of cancer cells. In our study, CAGE mRNA was expressed in $39.4 \%$ of HCC patients, $73.3 \%$ of patients with gastric cancer and $30.8 \%$ of patients with colorectal cancer. Antibodies against CAGE protein were detected in approximately $5.1 \%$ of the sera from HCC patients, $8.3 \%$ of that from gastric cancer patients and $7.3 \%$ of that from colorectal cancer patients. The relative high incidence of CAGE in cancer cells makes it a potential target for vaccine design. Another antigen of great interest is transgelin 2. The overexpression of transgelin $2 \mathrm{mRNA}$ in a large per cent (69\%) of HCC points to its potential as a diagnostic marker for HCC.
\end{abstract} British Journal of Cancer (2005) 92, 929-934. doi:I0.1038/sj.bjc.6602460 www.bjcancer.com (c) 2005 Cancer Research UK

Keywords: hepatocellular carcinoma; serological analysis of recombinant cDNA expression libraries; tumour antigens; cDNA microarray

The mortality rate of hepatocellular carcinoma (HCC) is extremely high in China and ranks the third in malignant tumours worldwide with a global incidence of 1.2 million new cases per year. Surgery remains the most effective treatment for HCC. However, only $20 \%$ of HCC patients can be resected and the recurrence in resected patients is as high as $70 \%$. Overall, the 5-year survival for resected patients is no more than $19 \%$. As for therapies using chemical or physical approaches, the outcome is still poor because of the resistance of cancer cells in spite of some recent advances. (Butterfield and Ribas, 2002).

Antigen-specific immunotherapy is an alternative approach for the treatment of HCC (van der Bruggen et al, 1991). Over the past decade, a number of clinical trials have been conducted to examine the potential for the activation of tumour-specific T cells in HCC patients, many have shown biological activity and a subset has shown antitumour efficacy (Iwashita et al, 2003; Butterfield, 2004; Kuang et al, 2004). Recent reports on clinical trial of AFP-based vaccine indicated that spontaneous AFP-specific immunologic responses had been induced in vaccinated HCC patients. Further study on AFP-based immunotherapy is ongoing (Butterfield et al, 2003; Butterfield, 2004). Screening for potent tumour antigens

\footnotetext{
*Correspondence: W-F Chen; E-mail: wfchen@public.bta.net.cn

${ }^{6}$ These authors contributed equally to this work

Received 7 October 2004; revised I January 2005; accepted 19 January 2005
}

capable of inducing vigorous T-cell response and blocking of tumour escape are the two major tools to improve the effectiveness of tumour antigen vaccines. Rapid identification of tumourassociated antigens by cytotoxic T-cell and antibody-based screening of cDNA expression libraries has provided attractive targets for cancer-specific immune response, which accelerates the progress of antigen-specific immunotherapy.

Cancer-testis (CT) antigens, which express in a wide range of different cancer types but not in normal tissues except for testis, ovary and placenta, are considered as tumour-specific shared antigens (Scanlan et al, 2002a). The category of CT antigens is the common target for tumour immunotherapy in clinical trials, for example, NY-ESO-1 is a potent CT antigen and its eliciting integrated cellular and humoral responses have been observed in vaccinated patients in clinical trials, with little or no toxicity (Jager et al, 2000; Chen et al, 2004; Davis et al, 2004). The spontaneous $\mathrm{CD}^{+}{ }^{+} \mathrm{T}$-cell response to HLA-A2-restricted NY-ESO-1b peptide in HCC has been reported by our group (Shang et al, 2004), and our application for clinical trial of NY-ESO-1b peptide vaccine for the immunotherapy in HCC patients is under way.

In an attempt to screen for potent tumour antigens expressed in HCC, serological analysis of cDNA expression libraries (SEREX) has been used to screen a newly constructed HCC expression library. A subset of 30 antigens was found to be associated with an HCC-related serological response, and 14 of these 30 antigens showed altered mRNA expression in HCC. The identification of these tumour antigens provided candidates for immunological 
applications and the molecular features for understanding tumorigenesis.

\section{MATERIALS AND METHODS}

\section{Tissue specimens and sera}

The cancer tissues, adjacent noncancerous tissues and sera were collected from Peking University teaching hospitals and the Resource Bank of Cancer Center, Sun Yat-Sen University with the informed consent of patients. Tissue samples were resected and frozen immediately in liquid nitrogen. Serum samples were collected and reserved at $-70^{\circ} \mathrm{C}$.

\section{Construction and immunoscreening of cDNA expression library}

Total RNAs were extracted from two moderately differentiated HCC specimens with Trizol reagent (Life Technologies, Gaithersburg, MD, USA), and then mRNAs were purified by the poly-(A) Track kit (Promega, Madison, WI, USA) and mixed at an equal ratio. The HCC library was constructed and screened as described before (Wang et al, 2004).

\section{DNA sequencing}

The cDNA inserts were sequenced using the BigDye Terminator Cycle Sequencing kit (PE Applied Biosystems, Foster City, CA, USA). The cDNA sequences were analysed using Genbank database (http://www.ncbi.nlm.nih.gov).

\section{cDNA microarrays}

Two independent pools of RNA from tumours and the corresponding noncancerous tissues were prepared by mixing aliquots of RNA isolated from cancer tissues of six well-differentiated HCC and their adjacent noncancerous tissues, respectively. Another two similar pools were prepared using RNA isolated from cancer tissues of six poorly-differentiated HCC and their adjacent noncancerous tissues, respectively. Each pool was composed of an equal amount of all six samples. The microarray hybridisation was performed at the Gene Company Limited using the Human Genome U133A GeneChip array and the Affymetrix GeneChip platform. Analysis of microarray data was performed with the software package of Affymetrix. In this study, the differential expression was considered as significant between HCC and adjacent noncancerous tissues when the ratio of signals between the same spots on different membranes was greater than 2, with 95\% confidence $(P \leqslant 0.5)$.

\section{Real-time quantitative reverse transcript-polymerase chain} reaction analysis (RT - PCR)

The quantitation of transcripts from 16 paired HCC and their adjacent noncancerous tissues was performed by real-time quantitative reverse transcript-polymerase chain reaction (RT PCR) (Schmittgen et al, 2000). Primers were designed using PrimerBank Database (Wang and Seed, 2003). The emission intensity of SYBR Green I bound to double-strand DNA was detected with the icycler system (Bio-Rad, Hercules, CA, USA). After an initial denaturation at $95^{\circ} \mathrm{C}$ for $3 \mathrm{~min}$, the PCR reactions were cycled 40 times as follows: $5 \mathrm{~s}$ at $95^{\circ} \mathrm{C}, 10 \mathrm{~s}$ at the appropriate annealing temperature and the extension duration at $72^{\circ} \mathrm{C}$ is based on the length of the target sequence. Fluorescence intensity was measured at the end of each elongation phase. The melting curve analysis was carried out immediately after amplification, following the manufacturer's instructions. The fold change in target gene relative to G3PDH endogenous control was expressed as $2^{-\Delta \Delta \mathrm{Ct}}$, where $\Delta \Delta \mathrm{Ct}=\left(\mathrm{Ct}_{\mathrm{Target}}-\mathrm{Ct}_{\mathrm{G} 3 \mathrm{PDH}}\right)_{\mathrm{T}}-\left(\mathrm{Ct}_{\mathrm{Target}}-\mathrm{Ct}_{\mathrm{G} 3 \mathrm{PDH}}\right)_{\mathrm{N}}$. T represents cancerous tissue and $\mathrm{N}$ represents adjacent tissue.

\section{RT - PCR analysis}

The expression frequency of CAGE gene was determined by RT PCR analysis. Total RNA from cancer tissues and paired adjacent noncancerous tissues was extracted and treated with RNase-free DNase before reverse transcription with Advantage RT for PCR kit (Clontech, Palo Alto, CA, USA). RT - PCR of CAGE was performed with 35 cycles of $30 \mathrm{~s}$ at $94^{\circ} \mathrm{C}, 25 \mathrm{~s}$ at $60^{\circ} \mathrm{C}$ and $30 \mathrm{~s}$ at $72^{\circ} \mathrm{C}$, followed by $7 \mathrm{~min}$ at $72^{\circ} \mathrm{C}$. The sequences of paired primers were as follows: CAGE sense, $5^{\prime}$-ccaaagcaacaagctgcatgtc- $3^{\prime}$; CAGE antisense, $5^{\prime}$ tcattcagcctcccaggagttg- $3^{\prime}$.

\section{Western blot analysis}

The serological reactivity of CAGE antigen was analysed by Western blot assay. The cDNA of CAGE was constructed into pQE31 expression vector, which was then used to transform Escherichia coli strain M15. The recombinant CAGE protein was induced by $1 \mathrm{~mm}$ IPTG. Purification of the CAGE protein with $6 \times$ His tag was performed using Ni-NTA affinity chromatography (Qiagen).

The purified CAGE protein was resolved on $12 \%$ SDS-PAGE, and then transferred onto a nitrocellulose membrane. The nitrocellulose membrane was incubated with sera (1:500 dilution) for $1 \mathrm{~h}$ after blocking with $5 \%$ low-fat milk. After washing, the NC membrane was incubated with alkaline phosphatase-conjugated goat anti-human IgG $(1: 15000$ dilution $)$ for $1 \mathrm{~h}$, and then processed for NBT/BCIP colour development.

\section{RESULTS}

\section{SEREX defined HCC-associated antigens}

Using SEREX to screen a newly constructed HCC cDNA expression library, 52 positive clones were obtained. Sequencing analysis showed that the 52 clones represented 30 distinct antigens (Table 1). Of these 30 antigens, one is the CT antigen CAGE protein, and the other 13 antigens, which had previously been reported to be involved in tumorigenesis or suspected to be involved in tumour progression, including CDC37 (Stepanova et al, 2000), MIF (Li et al, 2004), galectin 4 (Huflejt and Leffler, 2004), galectin 8 (Bidon-Wagner and Le Pennec, 2004), PINCH (WangRodriguez et al, 2002), SPRY2 (Lee et al, 2004a), HSPCA (Becker et al, 2004; Huang et al, 2004b), transgelin 2 (Shields et al, 2002), HDAC2 (Zhu et al, 2004), H factor (Junnikkala et al, 2000), AAT (Huang et al, 2004a), B factor (Perou et al, 1999), PIBF (Lachmann et al, 2004). Three other antigens (SR140 protein, SFRS2IP, RNPC2) may be involved in the regulation of alternative mRNA splicing, PSMA7 is related to hepatitis B and hepatitis C viral replication (Zhang et al, 2000; Kruger et al, 2001), and the remaining 12 antigens have no known association with cancer or hepatitis B or hepatitis C.

\section{Expression patterns of the mRNA transcripts encoding tumour antigens identified by SEREX from HCC}

With the intention to identify HCC tumour markers, expression patterns of the mRNA transcripts encoding serologically defined HCC antigens in HCC samples were evaluated by cDNA microarray analysis. Of the 30 antigens, 14 antigens showed differential mRNA expression in HCC samples relative to the adjacent noncancerous tissues. The mRNA expression levels of nine antigens, CAGE, transgelin2, HDAC2, RNPC2, PSMD1, HSPCA, PSMA7, U2-associated SR140 protein and galectin 4, were upregulated in HCC, whereas those of the other five antigens, 
Table I Genes cloned from hepatocellular carcinoma by SEREX

\begin{tabular}{|c|c|c|c|c|}
\hline No. & GenBank access no. & Gene & Clone repeat & Remark \\
\hline I & NM_000I86 & H factor I & 4 & A component of Complement System \\
\hline 2 & NM_001710 & B factor & 1 & A component of Complement System \\
\hline 3 & NM_000295 & AAT & 1 & Alpha I-antitrypsin \\
\hline 4 & NM_001735 & C5 & 1 & Complement component 5 \\
\hline 5 & NM_0I3450 & BAZ2B & 1 & Involved in chromatin remodelling \\
\hline 6 & NM_00I527 & HDAC2 & I & Regulating chromatin structure \\
\hline 7 & XM_03I553 & SRI40 protein & 5 & Involved in the regulation of alternative splicing \\
\hline 8 & NM_004719 & SFRS2IP & 1 & Splicing pre-mRNA \\
\hline 9 & NM_004902 & RNPC2 & 1 & Splicing factor \\
\hline 10 & NM_0I6224 & Sorting nexin 9 & 1 & Involved in intracellular trafficking \\
\hline | | & NM_001012 & RPS8 & 5 & Ribosomal protein S8 \\
\hline 12 & NM_007065 & CDC37 & 1 & Molecular chaperone \\
\hline 13 & NM_005348 & HSPCA & 1 & Molecular chaperone \\
\hline 14 & NM_002807 & PSMDI & 2 & A non-ATPase subunit \\
\hline 15 & NM_005176 & ATP5G2 & I & Subunit c of ATP synthase \\
\hline 16 & NM_002792 & PSMA7 & 1 & Proteasome subunit, alpha-type,7 \\
\hline 17 & NM_005842 & SPRY2 & I & Regulating epidermal growth factor receptor/mitogen-activated protein kinase \\
\hline 18 & NM_004987 & $\mathrm{PINCH}$ & 2 & Likely involved in integrin signalling \\
\hline 19 & NM_0024I5 & MIF & 1 & Migration inhibitory factor \\
\hline 20 & NM_01496I & RIPX & 4 & Rap2 interacting protein $\times$ \\
\hline 21 & NM_006499 & Galectin 8 & 1 & Involved in modulating cell-cell and cell-matrix interactions \\
\hline 22 & NM_006149 & Galectin 4 & 2 & Involved in modulating cell-cell and cell-matrix interactions \\
\hline 23 & NM_006346 & $\mathrm{PIBFI}$ & 1 & Progesterone-induced blocking factor I \\
\hline 24 & NM_003564 & Transgelin 2 & 2 & Involving in cell proliferation and migration \\
\hline 25 & XM_042860 & KIAA0379 & 1 & Hypothetical protein \\
\hline 26 & AF543495 & Melanoma-associated antigen & I & Function unknown \\
\hline 27 & NM_0I6436 & HCA58 & 2 & Function unknown \\
\hline 28 & NM_032639 & FAPP2 & 3 & Phosphoinositol 4-phosphate adaptor protein-2 \\
\hline 29 & NM_0I8326 & HIMAP4 & 1 & Homo sapien immunity-associated protein 4 \\
\hline 30 & AY039237 & CAGE & 1 & $\mathrm{CT}$ antigen \\
\hline
\end{tabular}

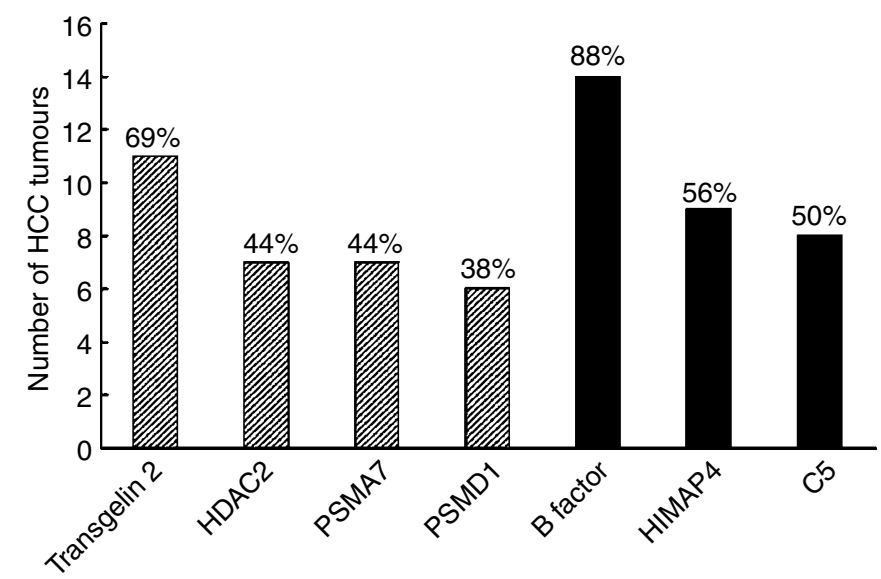

Figure I Seven differentially expressed antigens in HCC tissues measured by real-time quantitative RT-PCR. The frequencies for each altered gene out of 16 paired $\mathrm{HCC}$ are indicated on the top of each graphic bar (shadowed bars: overexpressed genes; solid black bars: downregulated genes).

HIMAP4, H factor, C5, AAT and B factor, were downregulated. To validate the cDNA microarray results, with the exception of CAGE, as well as HSPCA and galectin 4, which have been already reported to be overexpressed in HCC (Huang et al, 2004b; Huflejt and Leffler, 2004), the mRNA expression levels of seven antigens out of the remaining 11 antigens were further measured by real-time quantitative RT-PCR. Altered mRNA expression was defined as two-fold differences in the expression level in HCC relative to paired adjacent noncancerous tissue. Figure 1 summarised the quantitative RT-PCR results from 16 pairs of HCC tissues. Three antigens including B factor, HIMAP4 and C5 had downregulated mRNA expression in HCC relative to the adjacent noncancerous tissue, at frequencies of 88,56 and $50 \%$, respectively, and four other antigens including transgelin 2, PSMA7, HDAC2 and PSMD1 were overexpressed at frequencies of $69,44,44$ and $38 \%$, respectively. Of note, transgelin 2 was overexpressed at a high rate $(69 \%)$ in HCC specimens.

\section{Expression of CAGE in different tumour entities}

CAGE is a CT antigen identified from a testis library by Cho et al (2002). To investigate the distribution of CAGE mRNA in HCC, the cancer tissues and paired adjacent tissues were examined by RT PCR. CAGE mRNA was expressed in $39.4 \%$ (13 of 33) of HCC tissues and in $9.1 \%$ (three of 33 ) of HCC adjacent noncancerous tissues. Representative results are shown in Figure 2. In gastric cancer, CAGE mRNA was detected in $73.3 \%$ (11 of 15) of cancerous tissues and in $33.3 \%$ (five of 15) of noncancerous tissues. In colorectal cancer, the CAGE mRNA expression rate was $30.8 \%$ (four of 13) and 15.4\% (two of 13), respectively.

\section{Serological reactivity of recombinant CAGE protein in cancer patients}

To determine the anti-CAGE antibodies produced in tumour patients, sera collected from patients with HCC, gastric cancer or colorectal cancer were screened by Western blot assay with the recombinant CAGE protein. Positive reaction was detected in $5.1 \%$ (four of 79) of HCC patients. Clinical histopathological diagnoses were available for three of the four patients who had serum antibody. Two patients were at stage II and one patient at stage III. The percentage of positive reaction was $8.3 \%$ (three of 36 ) in gastric cancer and $7.3 \%$ (three of 41 ) in colorectal cancer, and all 


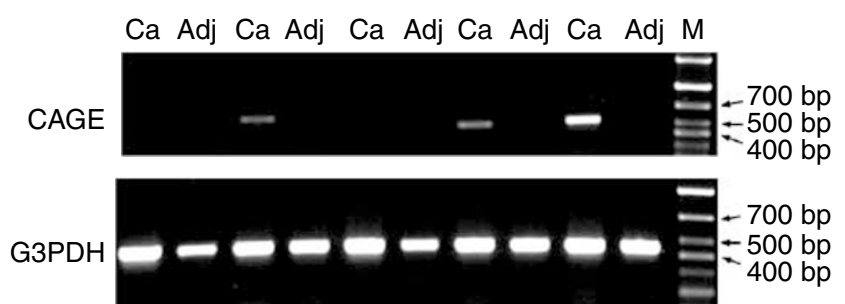

Figure 2 Expression of CAGE in representative HCC samples and paired adjacent noncancerous tissues by RT-PCR. CAGE was detected in three HCC tissues as a 529-bp PCR product. The expression of CAGE was negative in five paired adjacent noncancerous tissues. RT-PCR for G3PDH was used to monitor the quality of the RNA sample with a 452-bp PCR product (Ca: cancerous tissues; Adj: adjacent noncancerous tissues; $M$ : marker).

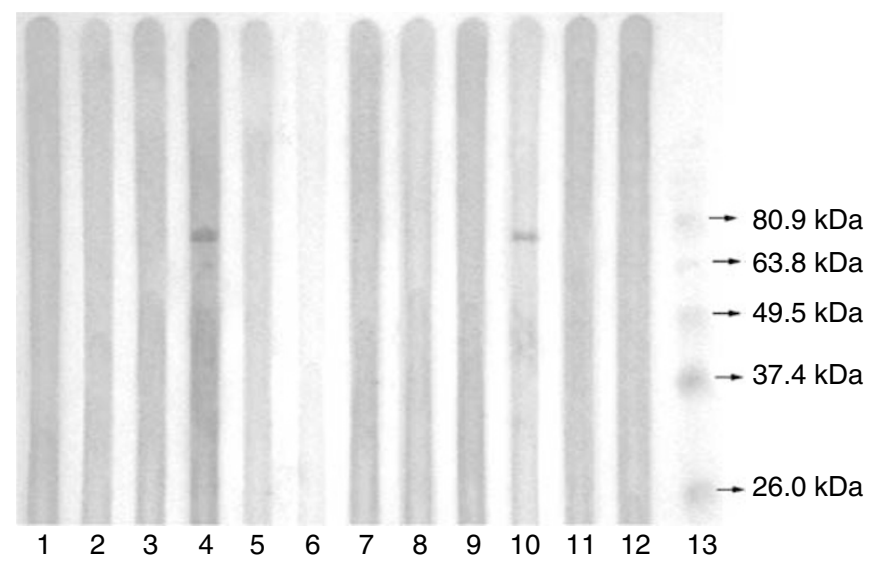

Figure 3 Serological reactivity of the recombinant CAGE protein in HCC patients by Western blot assay. Lane 13: protein marker; lanes II 12: negative controls with normal sera; lane 10: positive control with the pooled sera, with which the HCC cDNA expression library was immunoscreened; lane 4: positive reaction with an HCC serum; lanes I3 and 5-9: negative reaction with HCC sera.

these six patients had the cancer at stage III. Representative results were shown in Figure 3.

\section{DISCUSSION}

SEREX has been proved to be an easy and effective approach for the identification of tumour antigens, and so far about 1200 SEREX-defined tumour antigens have been identified. Given that the size of the SEREX-defined cancer immunome, the repertoire of tumour antigens capable of eliciting immune response in cancer patients, is estimated to have 4000 antigens, continued efforts in SEREX screening should extend our understanding of tumour antigens (Lee et al, 2004b). With the aim to identify potent tumour-associated antigens for clinical applications, the SEREX screening of HCC cDNA expression library was performed in several laboratories (Stenner-Liewen et al, 2000; Wang et al, 2002; Uemura et al, 2003). These findings imply that different tumourassociated antigens may be identified by SEREX from distinct HCC samples. In this study, we established a pooled cDNA library from two patients with HCC and screened it with pooled sera. A total of 30 antigens reactive with serum IgG from HCC patients were identified, which include 14 antigens reported to be involved in tumorigenesis or suspected to be related to tumour progression. Of these, one is CT antigen (CAGE), which was first reported to be expressed in gastric cancer by Cho et al (2002) and found to be hypomethylated in the majority specimens of human HCC (Cho et al, 2003). Intriguingly, none of the 30 antigens overlapped with the antigens detected by the other two groups (Stenner-Liewen et al, 2000; Uemura et al, 2003), and only one of them (HCA58) was identified in our previous report (Wang et al, 2002).

Knowledge in the immunogenicity and expression pattern of serologically defined tumour antigens is critical in assessing their relevance to cancer and their therapeutic and diagnostic potentials. CT antigens, with restricted expression in normal gametogenic tissues and aberrantly expressed in a wide range of cancers, are considered to be ideal targets for cancer vaccination today. In the present study, the expression of CT antigen CAGE in HCC was first identified by antibody-based screening of SEREX and subsequently found to be overexpressed at mRNA level in 39.4\% (13 of 33) of HCC specimens, $73.3 \%$ (11 of 15) of gastric cancer samples, and $30.8 \%$ (four of 13 ) of colorectal cancer samples. Antibody response was detected in $5.1 \%$ (four of 79 ) of the HCC patients, $8.3 \%$ (three of 36) of the gastric cancer patients and 7.3\% (three of 41) of the patients with colorectal cancer. Thus, we have confirmed the high expression of CAGE mRNA in gastric cancer as reported by Cho et al (2002, 2003), and revealed the intermediate expression of CAGE in HCC and colorectal cancer. We also demonstrated that CAGE was immunogenic to elicit antibody response in cancer patients. As a CT antigen, CAGE might be a potential candidate for tumour vaccine design, provided it is proved that CAGE can induce $\mathrm{T}$-cell responses.

We are aware that CAGE was detected to be expressed in minor but substantial number of adjacent noncancerous tissue specimens, $9.1 \%$ (three of 33 ), 33.3\% (five of 15 ) and $15.4 \%$ (two of 13 ) in adjacent noncancerous tissues of HCC, gastric cancer and colorectal cancers, respectively. To define the cell types expressing CAGE mRNA in the adjacent noncancerous tissues, in situ hybridisation and histochemical staining were performed in the consecutive slides of the HCC adjacent noncancerous tissues with CAGE mRNA expression. Our results showed that these noncancerous tissues were in cirrhotic condition and some of the cirrhotic hepatocytes expressed CAGE mRNA (data not shown). As the cirrhosis was considered to be precancerous condition (Kanai et al, 2004), the positive signal of CAGE mRNA in cirrhotic hepatocytes might imply that these cells are at the transitional stage towards the HCC. To ensure whether CAGE was expressed in cirrhosis tissues, 19 cirrhosis samples were collected for further analysis of the expression of CAGE mRNA, and two of the 19 samples were observed to be positive (data not shown). A recent study by Cho and collegues has provided evidence for promoter hypomethylation of CAGE in the premalignant stage of gastric carcinoma and HCC (Cho et al, 2003). It is perceivable that CAGE is associated with the progression of tumorigenesis. Thereby, it may be worthwhile monitoring CAGE mRNA expression in patients with liver cirrhosis and observing the probability to develop into HCC.

In conformity with previous reports (Scanlan et al, 2002b; Wang et al, 2002) that a subset of antigens with cancer-related serological profile was encoded by the genes of altered expression, in this study, 14 of the antigens associated with an HCC-related serological response showed altered levels of mRNA expression, including five antigens, HIMAP4 , B factor, C5, AAT and H factor, which had a lower level of mRNA expression in HCC relative to the adjacent noncancerous tissues. AAT was found to inhibit angiogenesis and tumour growth, its downregulation in cancer may associate with tumour progression (Huang et al, 2004a). Four other antigens associate with the inhibition of immune responses, and hence may facilitate tumour escaping.

Nine of the antigens associated with an HCC-related serological response, CAGE, SR140 protein, HSPCA, PSMD1, HDAC2, RNPC2, galectin 4, transgelin 2 and PSMA7, were overexpressed in HCC. 
Transgelin 2, which has been reported to be overexpressed in gastric cancer (Ryu et al, 2003), was found to be upregulated in 11 of 16 HCC patients. This protein is thought to be involved in cell proliferation and migration, suggesting that its overexpression may be implicated in tumour progression. The fact that transgelin 2 was overexpressed and detected at a high rate $(69 \%)$ in HCC specimens has made this molecule a candidate HCC marker for diagnosis. HDAC2, which is considered as a key element in the dynamic regulation of many genes regulating cellular proliferation and differentiation during carcinogenesis (Cress and Seto, 2000), was found to be upregulated in seven of 16 HCC patients, suggesting that its overexpression may have aetiologic significance. A recent report showed that elevated HDAC2 mRNA expression was observed in $82 \%$ of 57 human colonic cancer patients ( $\mathrm{Zhu}$ et al, 2004). In addition, a large number of studies have shown that HDAC inhibitors can effectively arrest and revert transformation of some cells and block the formation of tumours in rodent models. These observations suggest that HDAC inhibitors may be candidate drugs in therapy for human cancer (Cress and Seto, 2000). PSMA7, which was found to be overexpressed in seven of 16 HCC patients, is a subunit of proteasome, and has been shown to interact specifically with the hepatitis $B$ virus $\mathrm{x}$ protein, a protein critical to viral replication (Zhang et al, 2000). It is also involved in regulating hepatitis virus $C$ internal ribosome entry site activity, which is essential for viral replication (Kruger et al, 2001). In consideration of the close correlation of hepatitis with HCC, upregulation of PSMA7 in HCC may play an important role in aetiopathogenesis of HCC. PSMD1, which is involved in processing of class 1 MHC peptide (Coux et al, 1996), was found to be overexpressed in six of 16 HCC patients. However, its association with tumour is less obvious. Transcripts encoding 2 other antigens with cancer-related serological profiles, HSPCA and galectin 4, have been reported to be overexpressed in 45\% (20 of 45) (Huang et al, 2004b) and $80 \%$ (four of five) (Kondoh et al, 1999) in HCC patients, respectively; their upregulation in HCC may associate with occurrence and progression of tumour. As regulator for premRNA splicing, overexpression of RNPC2 and SR140 protein may also be of aetiological significance in HCC.

In the attempt to find HCC tumour markers among our SEREXidentified 30 antigens, the mRNA expression level was quantitatively measured by cDNA microarray and real-time PCR, and there were nine genes upregulated, five genes downregulated and 16 genes unaltered. These results indicate that the immunogenicity of autoantigens in cancer patients is not closely correlated with their mRNA expression levels. An immune response to apparently unaltered gene products in cancer patients might be due to the crossreaction of the antibodies generated against the mutated product in cancer patients with the unaltered wild-type gene product (Scanlan et al, 1998). Alternatively, the bystanding help effect in cancer patients may activate autoantigens to induce antibody response.

Overall, our SEREX-identified new tumour antigens in HCC add more information in HCC immunome, which may help in understanding the HCC tumorigenesis. And the SEREX-defined CT antigen CAGE in HCC may be a potential candidate for tumour vaccine design and transgelin 2 might be an HCC tumour marker for diagnosis.

\section{ACKNOWLEDGEMENTS}

This work was supported by grants from China National 863 Program (2003AA215110), Ludwig Institute for Cancer Research (KSP 003) and Beijing Municipal Government Foundation for National Sciences (7001002).

\section{REFERENCES}

Becker B, Multhoff G, Farkas B, Wild PJ, Landthaler M, Stolz W, Vogt T (2004) Induction of Hsp90 protein expression in malignant melanomas and melanoma metastases. Exp Dermatol 13: 27 -32

Bidon-Wagner N, Le Pennec JP (2004) Human galectin-8 isoforms and cancer. Glycoconjugation J 19: $557-563$

Butterfield LH (2004) Immunotherapeutic strategies for hepatocellular carcinoma. Gastroenterology 127: S232-S241

Butterfield LH, Ribas A (2002) Immunotherapy of hepatocellular carcinoma. Expert Opin Biol Ther 2: $123-133$

Butterfield LH, Ribas A, Meng WS, Dissette VB, Amarnani S, Vu HT, Seja E, Todd K, Glaspy JA, McBride WH, Economou JS (2003) T-cell responses to HLA-A ${ }^{\star} 0201$ immunodominant peptides derived from alpha-fetoprotein in patients with hepatocellular cancer. Clin Cancer Res 9: $5902-5908$

Chen Q, Jackson H, Parente P, Luke T, Rizkalla M, Tai TY, Zhu HC, Mifsud NA, Dimopoulos N, Masterman KA, Hopkins W, Goldie H, Maraskovsky E, Green S, Miloradovic L, McCluskey J, Old LJ, Davis ID, Cebon J, Chen W (2004) Immunodominant CD4+ responses identified in a patient vaccinated with full-length NY-ESO-1 formulated with ISCOMATRIX adjuvant. Proc Natl Acad Sci USA 101: $9363-9368$

Cho B, Lee H, Jeong S, Bang YJ, Lee HJ, Hwang KS, Kim HY, Lee YS, Kang GH, Jeoung DI (2003) Promoter hypomethylation of a novel cancer/testis antigen gene CAGE is correlated with its aberrant expression and is seen in premalignant stage of gastric carcinoma. Biochem Biophys Res Commun 307: $52-63$

Cho B, Lim Y, Lee DY, Park SY, Lee H, Kim WH, Yang H, Bang YJ, Jeoung DI (2002) Identification and characterization of a novel cancer/testis antigen gene CAGE. Biochem Biophys Res Commun 292: 715-726

Coux O, Tanaka K, Goldberg AL (1996) Structure and functions of the 20S and 26S proteasomes. Annu Rev Biochem 65: $801-847$

Cress WD, Seto E (2000) Histone deacetylases, transcriptional control, and cancer. J Cell Physiol 184: 1-16

Davis ID, Chen W, Jackson H, Parente P, Shackleton M, Hopkins W, Chen Q, Dimopoulos N, Luke T, Murphy R, Scott AM, Maraskovsky E,
McArthur G, MacGregor D, Sturrock S, Tai TY, Green S, Cuthbertson A, Maher D, Miloradovic L, Mitchell SV, Ritter G, Jungbluth AA, Chen YT, Gnjatic S, Hoffman EW, Old LJ, Cebon JS (2004) Recombinant NY-ESO-1 protein with ISCOMATRIX adjuvant induces broad integrated antibody and CD4(+) and CD8(+) T cell responses in humans. Proc Natl Acad Sci USA 101: $10697-10702$

Huang H, Campbell SC, Nelius T, Bedford DF, Veliceasa D, Bouck NP, Volpert OV (2004a) Alpha1-antitrypsin inhibits angiogenesis and tumour growth. Int J Cancer 112: $1042-1048$

Huang JS, Chao CC, Su TL, Yeh SH, Chen DS, Chen CT, Chen PJ, Jou YS (2004b) Diverse cellular transformation capability of overexpressed genes in human hepatocellular carcinoma. Biochem Biophys Res Commun 315: $950-958$

Huflejt ME, Leffler H (2004) Galectin-4 in normal tissues and cancer. Glycoconjugation J 20: 247-255

Iwashita Y, Tahara K, Goto S, Sasaki A, Kai S, Seike M, Chen CL, Kawano K, Kitano S (2003) A phase I study of autologous dendritic cell-based immunotherapy for patients with unresectable primary liver cancer. Cancer Immunol Immunother 52: 155-161

Jager E, Gnjatic S, Nagata Y, Stockert E, Jager D, Karbach J, Neumann A, Rieckenberg J, Chen YT, Ritter G, Hoffman E, Arand M, Old LJ, Knuth A (2000) Induction of primary NY-ESO-1 immunity: $\mathrm{CD} 8+\mathrm{T}$ lymphocyte and antibody responses in peptide-vaccinated patients with NY-ESO-1+ cancers. Proc Natl Acad Sci USA 97: $12198-12203$

Junnikkala S, Jokiranta TS, Friese MA, Jarva H, Zipfel PF, Meri S (2000) Exceptional resistance of human $\mathrm{H} 2$ glioblastoma cells to complementmediated killing by expression and utilization of factor $\mathrm{H}$ and factor $\mathrm{H}$ like protein 1. J Immunol 164: 6075-6081

Kanai Y, Saito Y, Ushijima S, Hirohashi S (2004) Alterations in gene expression associated with the overexpression of a splice variant of DNA methyltransferase 3b, DNMT3b4, during human hepatocarcinogenesis. J Cancer Res Clin Oncol 130: 636-644 
Kondoh N, Wakatsuki T, Ryo A, Hada A, Aihara T, Horiuchi S, Goseki N, Matsubara O, Takenaka K, Shichita M, Tanaka K, Shuda M, Yamamoto M (1999) Identification and characterization of genes associated with human hepatocellular carcinogenesis. Cancer Res 59: 4990-4996

Kruger M, Beger C, Welch PJ, Barber JR, Manns MP, Wong-Staal F (2001) Involvement of proteasome alpha-subunit PSMA7 in hepatitis $\mathrm{C}$ virus internal ribosome entry site-mediated translation. Mol Cell Biol 21: $8357-8364$

Kuang M, Peng BG, Lu MD, Liang LJ, Huang JF, He Q, Hua YP, Totsuka S, Liu SQ, Leong KW, Ohno T (2004) Phase II randomized trial of autologous formalin-fixed tumour vaccine for postsurgical recurrence of hepatocellular carcinoma. Clin Cancer Res 10: 1574-1579

Lachmann M, Gelbmann D, Kalman E, Polgar B, Buschle M, Von Gabain A, Szekeres-Bartho J, Nagy E (2004) PIBF (progesterone induced blocking factor) is overexpressed in highly proliferating cells and associated with the centrosome. Int J Cancer 112: 51-60

Lee CC, Putnam AJ, Miranti CK, Gustafson M, Wang LM, Vande Woude GF, Gao CF (2004a) Overexpression of sprouty 2 inhibits HGF/SFmediated cell growth, invasion, migration, and cytokinesis. Oncogene 23: $5193-5202$

Lee SY, Williamson B, Caballero OL, Chen YT, Scanlan MJ, Ritter G, Jongeneel CV, Simpson AJ, Old LJ (2004b) Identification of the gonadspecific anion transporter SLCO6Al as a cancer/testis (CT) antigen expressed in human lung cancer. Cancer Immun 4: 13

Li Y, Lu C, Xing G, Zhu Y, He F (2004) Macrophage migration inhibitory factor directly interacts with hepatopoietin and regulates the proliferation of hepatoma cell. Exp Cell Res 300: 379-387

Perou CM, Jeffrey SS, van de Rijn M, Rees CA, Eisen MB, Ross DT, Pergamenschikov A, Williams CF, Zhu SX, Lee JC, Lashkari D, Shalon D, Brown PO, Botstein D (1999) Distinctive gene expression patterns in human mammary epithelial cells and breast cancers. Proc Natl Acad Sci USA 96: $9212-9217$

Ryu JW, Kim HJ, Lee YS, Myong NH, Hwang CH, Lee GS, Yom HC (2003) The proteomics approach to find biomarkers in gastric cancer. $J$ Korean Med Sci 18: 505-509

Scanlan MJ, Chen YT, Williamson B, Gure AO, Stockert E, Gordan JD, Tureci O, Sahin U, Pfreundschuh M, Old LJ (1998) Characterization of human colon cancer antigens recognized by autologous antibodies. Int $J$ Cancer 76: $652-658$

Scanlan MJ, Gure AO, Jungbluth AA, Old LJ, Chen YT (2002a) Cancer/testis antigens: an expanding family of targets for cancer immunotherapy. Immunol Rev 188: 22 - 32

Scanlan MJ, Welt S, Gordon CM, Chen YT, Gure AO, Stockert E, Jungbluth AA, Ritter G, Jager D, Jager E, Knuth A, Old LJ (2002b) Cancer-related serological recognition of human colon cancer: identification of potential diagnostic and immunotherapeutic targets. Cancer Res 62: $4041-4047$
Schmittgen TD, Zakrajsek BA, Mills AG, Gorn V, Singer MJ, Reed MW (2000) Quantitative reverse transcription-polymerase chain reaction to study mRNA decay: comparison of endpoint and real-time methods. Anal Biochem 285: $194-204$

Shang XY, Chen HS, Zhang HG, Pang XW, Qiao H, Peng JR, Qin LL, Fei R, Mei MH, Leng XS, Gnjatic S, Ritter G, Simpson AJ, Old LJ, Chen WF (2004) The spontaneous CD8+ T-cell response to HLA-A2-restricted NYESO-1b peptide in hepatocellular carcinoma patients. Clin Cancer Res 10: $6946-6955$

Shields JM, Rogers-Graham K, Der CJ (2002) Loss of transgelin in breast and colon tumors and in RIE-1 cells by Ras deregulation of gene expression through Raf-independent pathways. J Biol Chem 277: 9790-9799

Stenner-Liewen F, Luo G, Sahin U, Tureci O, Koslovski M, Kautz I, Liewen H, Pfreundschuh M (2000) Definition of tumor-associated antigens in hepatocellular carcinoma. Cancer Epidemiol Biomarkers Prev 9: 285-290

Stepanova L, Yang G, DeMayo F, Wheeler TM, Finegold M, Thompson TC, Harper JW (2000) Induction of human Cdc37 in prostate cancer correlates with the ability of targeted Cdc37 expression to promote prostatic hyperplasia. Oncogene 19: 2186-2193

Uemura M, Nouso K, Kobayashi Y, Tanaka H, Nakamura S, Higashi T, Ono T, Nakayama E, Hanafusa T, Shiratori Y (2003) Identification of the antigens predominantly reacted with serum from patients with hepatocellular carcinoma. Cancer 97: 2474-2479

van der Bruggen P, Traversari C, Chomez P, Lurquin C, De Plaen E, Van den Eynde B, Knuth A, Boon T (1991) A gene encoding an antigen recognized by cytolytic $\mathrm{T}$ lymphocytes on a human melanoma. Science 254: $1643-1647$

Wang HC, Su YR, Han KJ, Pang XW, Peng JR, Liang B, Wang S, Chen WF (2004) Multiple variants and a differential splicing pattern of kinectin in human hepatocellular carcinoma. Biochem Cell Biol 82: 321 - 327

Wang X, Seed B (2003) A PCR primer bank for quantitative gene expression analysis. Nucleic Acids Res 31: e154

Wang Y, Han KJ, Pang XW, Vaughan HA, Qu W, Dong XY, Peng JR, Zhao HT, Rui JA, Leng XS, Cebon J, Burgess AW, Chen WF (2002) Large scale identification of human hepatocellular carcinoma-associated antigens by autoantibodies. J Immunol 169: $1102-1109$

Wang-Rodriguez J, Dreilinger AD, Alsharabi GM, Rearden A (2002) The signaling adapter protein PINCH is up-regulated in the stroma of common cancers, notably at invasive edges. Cancer 95: 1387-1395

Zhang Z, Torii N, Furusaka A, Malayaman N, Hu Z, Liang TJ (2000) Structural and functional characterization of interaction between hepatitis B virus X protein and the proteasome complex. J Biol Chem 275: $15157-15165$

Zhu P, Martin E, Mengwasser J, Schlag P, Janssen KP, Gottlicher M (2004) Induction of HDAC2 expression upon loss of APC in colorectal tumorigenesis. Cancer Cell 5: $455-463$ 